\title{
Association Between Pseudoxanthoma Elasticum and Bleeding
}

\author{
Lily Lebwohl' ${ }^{1}$, Robert Phelps, MD ${ }^{1}$ \\ ${ }^{1}$ Icahn School of Medicine at Mount Sinai, New York, NY
}

\section{ABSTRACT}

Pseudoxanthoma Elasticum (PXE) is a rare genetic disease caused by a mutation of the ABCC6 gene, resulting in calcification of elastic fibers of the skin, eye and other organs and tissues that contain elastin. Because calcified arteries can bleed, hemorrhage from various organs is a reported complication of PXE. We conducted a literature review of all English language published articles reporting bleeding in patients with PXE. In this literature review, we identified 51 papers. Of those, 30 $(59 \%)$ included at least 1 case of bleeding. Within these 30 papers, bleeding was reported in a total of 130 patients. Of the cases of bleeding, 113 occurred in the gastrointestinal tract, 12 occurred in the brain, 2 in the skin, 1 in the nose, 1 in the gums and 1 in the uterus. Clinicians and patients should be made aware of the risk of these significant complications, to facilitate preventive measures, prompt recognition and treatment.

\section{INTRODUCTION}

Pseudoxanthoma Elasticum (PXE) is a rare genetic disease caused by a mutation of the ABCC6 gene. This results in calcification of elastic fibers of the skin, eye and other organs and tissues that contain elastin. The internal elastic lamina of arteries can be affected, resulting in vascular complications including bleeding. Ringpfeil et. al. described mutations in the ABCC6 transporter protein inherited in a an autosomal recessive pattern in PXE. ${ }^{1}$ Consequently, any organ containing elastic tissue can be affected, with skin $^{2}$ and eyes ${ }^{3}$ being the most common. Skin lesions are characterized by yellow xanthoma-like patches, papules and folds (figure 1A,1B). Mucosal lesions have also been described, particularly on the oral mucosa (figure 2). and the classic eye characteristics are angioid streaks in the retina (figure 3) ${ }^{4}$ though any elastic- containing tissue can be affected. Heart valves can be involved, resulting in mitral valve prolapse ${ }^{5}$ and myocardial infarctions at an early $a^{6} \mathrm{e}^{6}$. The latter complication occurs as a consequence of calcification of the coronary arteries.

PXE can be identified at any age and has been reported in ages as young as age $4 .{ }^{7}$ It is associated with numerous complications including characteristic skin lesions (Figure $1 \mathrm{~A}, 1 \mathrm{~B})$ and angioid streaks in the retina (Figure 3). Serious vascular complications including myocardial infarction and stroke at a young age have been reported ${ }^{8}$. Because calcified arteries can bleed, hemorrhage from various organs is a reported complication of PXE. We therefore conducted a literature review of all English language published articles reporting bleeding in patients with PXE. 


\section{SKIN}

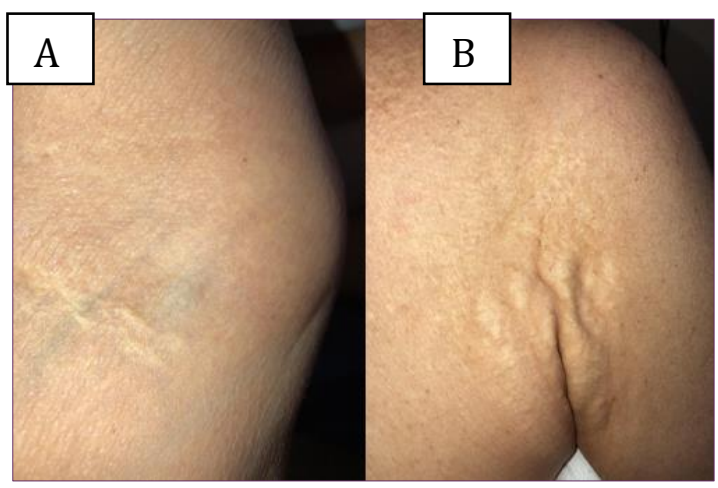

Figure 1. A) Yellow xanthoma-like papules typical of PXE B) Papules become confluent to form redundant folds in the axilla.

\section{METHODS}

A PubMed search was conducted using these terms: bleed, hemorrhage, haemorrhage, and pseudoxanthoma elasticum. Review articles were not included, nor were articles that did not include original cases of bleeding or hemorrhage. For reasons of scope, we did not include retinal bleeding in this review. For each report, we recorded the year of publication, number of subjects with PXE, the number with a bleeding event, the site of bleeding, and other complications among those with bleeding.

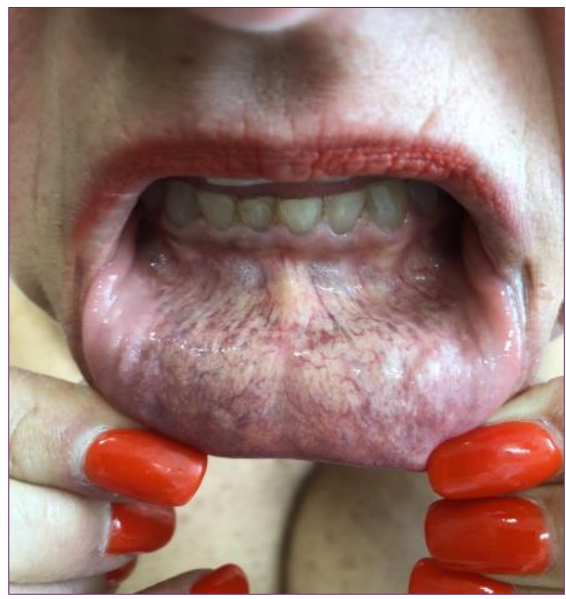

Figure 2. Yellow papules and patches on the lower lip.

\section{RESULTS}

Using the search terms outlined above, we identified 51 papers. Of those, 30 (59\%) included at least 1 case of bleeding. ${ }^{9-38}$ (The 21 remaining papers were excluded because they were review articles or did not include cases.) Within these 30 papers, bleeding was reported in a total of 130 patients. Of the cases of bleeding, 113 occurred in the gastrointestinal tract, 12 occurred in the brain, 2 in the skin, 1 in the nose, 1 in the gums and 1 in the uterus (see Table 1).

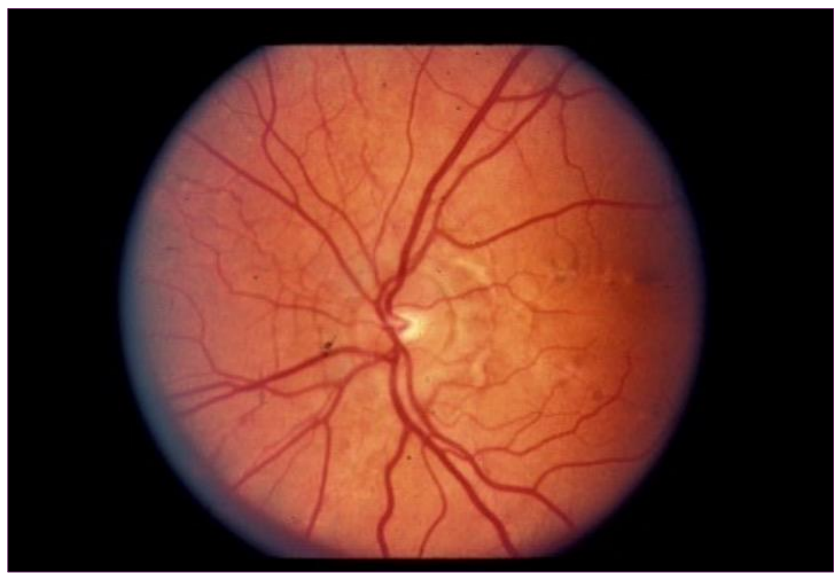

Figure 3. Angioid streaks of the retina

January 2022 Volume 6 Issue 1 


\section{DISCUSSION}

Figure 4 shows calcified elastic fibers in the skin biopsy of a patient with PXE. Retinal bleeding is very common, but bleeding at other sites can also occur and is the subject of this review. There were many sites of Table 1

\begin{tabular}{|c|c|c|c|c|c|}
\hline Year & Author & Site of Bleeding & $\begin{array}{l}\text { Other } \\
\text { complications }\end{array}$ & $\begin{array}{l}\text { Number } \\
\text { in } \\
\text { study }\end{array}$ & Number with bleeding \\
\hline 2020 & Sunmonu NA & Brain & stroke & 1 & 1 \\
\hline 2021 & Lanfranconi S & Brain & stroke & 1 & 1 \\
\hline 2016 & Dibi A & gastrointestinal & vascular disease & 2 & 2 \\
\hline 2014 & Drue HC & brain & & 1 & 1 \\
\hline 2008 & Adam AM & gums & & 1 & 1 \\
\hline 2008 & Bock A & brain & & 1 & 1 \\
\hline 2007 & Goral V & gastrointestinal & & 1 & 1 \\
\hline 2006 & Antiga E & gastrointestinal & & 1 & 1 \\
\hline 2005 & Golliet-Mercier N & gastrointestinal & & 1 & 1 \\
\hline 2004 & Makharia GK & gastrointestinal & & 1 & 1 \\
\hline 2002 & Ospedale S & gastrointestinal/intercranial & $\begin{array}{l}\text { gastric artery } \\
\text { aneurysm/ischaemic } \\
\text { attack }\end{array}$ & 29 & 2 \\
\hline 1996 & Spinzi G & gastrointestinal & & 2 & 2 \\
\hline 2000 & $\begin{array}{l}\text { Costopanagiotou } \\
\mathrm{E}\end{array}$ & gastrointestinal & & 1 & 1 \\
\hline 1992 & Yap EY & gastrointestinal & $\begin{array}{l}\text { aneurysms of the } \\
\text { gastric arteries }\end{array}$ & 1 & 1 \\
\hline 1991 & Yamamura $\mathrm{H}$ & gastrointestinal & & 1 & 1 \\
\hline 1990 & Slade AK & gastrointestinal & & 1 & 1 \\
\hline 1988 & Jacyk WK & gastrointestinal & & 7 & 1 \\
\hline 1988 & Kundrotas L & gastrointestinal & & 1 & 1 \\
\hline 1988 & Belli A & gastrointestinal & $\begin{array}{l}\text { vascular } \\
\text { abnormalities }\end{array}$ & 2 & 2 \\
\hline 1982 & Drost $\mathrm{H}$ & gastrointestinal & & 1 & 1 \\
\hline 1982 & Morgan AA & gastrointestinal & & 1 & 1 \\
\hline 1980 & Keim HJ & gastrointestinal & $\begin{array}{l}\text { total gastrectomy } \\
\text { and partial jejunal } \\
\text { resection }\end{array}$ & 1 & 1 \\
\hline 1973 & Olbromska W & gastrointestinal & & 1 & 1 \\
\hline 1973 & Van Waes L & gastrointestinal & & 1 & 1 \\
\hline 1968 & Gignoux R & gastrointestinal & total gastrectomy & 1 & 1 \\
\hline 1966 & Dhers A & gastrointestinal & & 3 & 3 \\
\hline 2000 & van den Berg JS & $\begin{array}{l}\text { gastrointestinal, skin, } \\
\text { nose, uterus }\end{array}$ & & 100 & $\begin{array}{l}17 \text { gastrointestinal; } 2 \\
\text { skin; } 1 \text { nose; } 1 \text { uterus }\end{array}$ \\
\hline 1967 & Grant AK & gastrointestinal & & 3 & 3 \\
\hline 2004 & Bercovitch L & gastrointestinal & & 306 & 66 \\
\hline 1988 & Neldner KH & gastrointestinal and brain & & 100 & 8 \\
\hline
\end{tabular}

January 2022 Volume 6 Issue 1 bleeding identified in this literature review, including the brain ${ }^{9}$, skin ${ }^{35}$, nose ${ }^{35}$, uterus ${ }^{35}$ and gums, ${ }^{13}$ but gastrointestinal bleeding was particularly common $11,15,28,30$, followed by cerebral hemorrhage ${ }^{12,14}$. Because of the bleeding tendency, certain management 
strategies can be used to minimize that adverse outcome. For example, the avoidance of blood thinners, aspirin and other non-steroidal anti-inflammatory drugs (NSAIDs) should be considered given these risks. Other activities known to be associated with gastrointestinal bleeding such as heavy alcohol consumption, cigarette smoking, and dual antiplatelet therapy should be avoided. Periodic checks of the stool for blood should be considered as part of the routine examination of patients with PXE. Because of the known risk of retinal bleeding and intracranial hemorrhage, trauma to the head should be avoided, and certain sports such as boxing or soccer may not be ideal for patients with PXE.

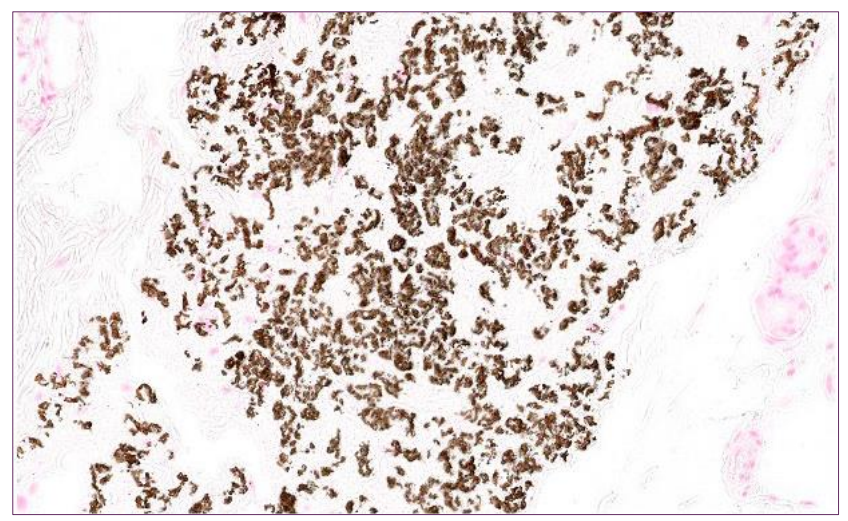

Figure 4. Calcified elastic fibers in the dermis of a patient with PXE

\section{CONCLUSION}

In summary, PXE is associated with bleeding from many sites. While retinal bleeding is most common, there are many reports of gastrointestinal followed by bleeding in the brain. Clinicians and patients should be made aware of the risk of these significant complications, to facilitate preventive measures, prompt recognition and treatment.
Conflict of Interest Disclosures: None

Funding: None

Corresponding Author:

Lily Lebwohl

The Leffell School

555 W Hartsdale Ave,

Hartsdale, NY 10530

Email: lilylebwohl@gmail.com

\section{References:}

1. Ringpfeil F, Lebwohl MG, Christiano AM, Uitto J. Pseudoxanthoma elasticum: mutations in the MRP6 gene encoding a transmembrane ATP-binding cassette (ABC) transporter. Proc Natl Acad Sci USA. 2000 May 23;97(11):6001-6.

2. Cui C, Zhou Z, Zhang Y, Sun D. A case report: pseudoxanthoma elasticum diagnosed based on ocular angioid streaks and the curative effect of Conbercept treatment. BMC Ophthalmol. 2021 Aug 23;21(1):307.

3. Nika M, Besirli CG. Choroidal neovascularization and angioid streaks in pseudoxanthoma elasticum. Int J Ophthalmol. 2011 Aug 18;4(4):449-51.

4. Marchese A, Rabiolo A, Corbelli E, Carnevali $A$, Cicinelli MV, Giuffrè $C$, et al. UltraWidefield Imaging in Patients with Angioid Streaks Secondary to Pseudoxanthoma Elasticum. Ophthalmol Retina. 2017;1(2):13744.

5. Lebwohl MG, Distefano D, Prioleau PG, Uram M, Yannuzzi LA, Fleischmajer R.

Pseudoxanthoma elasticum and mitral-valve prolapse. N Engl J Med. 1982 Jul 22;307(4):228-31.

6. Kieć-Wilk B, Surdacki A, Dembińska-Kieć A, Michalowska J, Stachura-Dereń M, Dubiel JS, et al. Acute myocardial infarction and a new ABCC6 mutation in a 16-year-old boy with pseudoxanthoma elasticum. Int J Cardiol. 2007 Mar 20;116(2):261-2.

7. Naouri M, Boisseau C, Bonicel P, Daudon P, Bonneau D, Chassaing N, et al.

Manifestations of pseudoxanthoma elasticum in childhood. Br J Dermatol. 2009

Sep;161(3):635-9.

8. Bertamino $M$, Severino $M$, Grossi A, Rusmini M, Tortora D, Gandolfo C, et al. ABCC6 mutations and early onset stroke: Two cases

January 2022 Volume 6 Issue 1 
of a typical Pseudoxanthoma Elasticum. Eur $\mathrm{J}$ Paediatr Neurol. 2018 Jul;22(4):725-8.

9. Sunmonu NA. Multiple cerebrovascular insults in pseudoxanthoma elasticum. J Stroke Cerebrovasc Dis. 2021 Mar;30(3):105524.

10. Lanfranconi S, Ghione I, Valcamonica G, Corti SP, Bonato S, Bresolin N. Safety and efficacy of rt-PA treatment for acute stroke in pseudoxanthoma elasticum: the first report. J Thromb Thrombolysis. 2021 Jan;51(1):176-9.

11. Dibi A, El Fahime EL, Mouane N, Dafiri R, Bentahila A. [Pseudoxanthoma elasticum: A rare cause of gastrointestinal bleeding in children]. Arch Pediatr. 2016 Jun;23(6):591-4.

12. Drue HC, Mogensen H, Olesen AW. [Pregnancy jeopardized by pseudoxanthoma elasticum]. Ugeskr Laeg. 2014 Oct 6;176(41).

13. Adam AM, Maritim MC. Pseudoxanthoma elasticum in a patient with sickle cell disease: case report. East Afr Med J. 2008 Feb;85(2):98-101.

14. Bock A, Schwegler G. Intracerebral haemorrhage as first manifestation of pseudoxanthoma elasticum. Clin Neurol Neurosurg. 2008 Mar;110(3):262-4.

15. Goral V, Demir D, Tuzun Y, Keklikci U, Buyukbayram H, Bayan K, et al.

Pseudoxantoma elasticum, as a repetitive upper gastrointestinal hemorrhage cause in a pregnant woman. World J Gastroenterol. 2007 Jul 28;13(28):3897-9.

16. Antiga E, Melani L, Caproni M, Fabbri P. An unusual cause of gastrointestinal bleeding in a young girl. CMAJ. 2006 Sep 12;175(6):583.

17. Golliet-Mercier N, Allaouchiche B, Monneuse O. [Pseudoxanthoma elasticum with severe gastrointestinal bleeding]. Ann Fr Anesth Reanim. 2005 Jul;24(7):833-4.

18. Makharia GK, Thapa BR, Poddar U, Narasimhan KL, Girish CS, Vaiphei K, et al. Pseudoxanthoma elasticum: a rare cause of recurrent gastrointestinal bleeding in a child. Indian J Gastroenterol. 2004 Dec;23(6):231-2.

19. Cianciulli P, Sorrentino F, Maffei L, Amadori S, Cappabianca MP, Foglietta E, et al.

Cardiovascular involvement in thalassaemic patients with pseudoxanthoma elasticum-like skin lesions: a long-term follow-up study. Eur J Clin Invest. 2002 Sep;32(9):700-6.

20. Spinzi G, Strocchi E, Imperiali G, Sangiovanni A, Terruzzi V, Minoli G. Pseudoxanthoma elasticum: a rare cause of gastrointestinal bleeding. Am J Gastroenterol. 1996 Aug;91(8):1631-4.
21. Costopanagiotou E, Spyrou S, Farantos C, Kostopanagiotou G, Smyrniotis V. An unusual cause of massive gastric bleeding in a young patient. Am J Gastroenterol. 2000 Sep;95(9):2400-1.

22. Yap EY, Gleaton MS, Buettner H. Visual loss associated with pseudoxanthoma elasticum. Retina (Philadelphia, Pa). 1992;12(4):315-9.

23. Yamamura $\mathrm{H}$, Hiraide $\mathrm{A}$, Tabuse $\mathrm{H}$, Yamamoto H, Sugimoto H, Yoshioka T, et al. [A case report of pseudoxanthoma elasticum with upper gastrointestinal hemorrhage]. Nippon Geka Gakkai Zasshi. 1991

Aug;92(8):1027-30.

24. Jacyk WK, Lodder JV, Dreyer L. Pseudoxanthoma elasticum in South African black patients. A report on 7 cases. S Afr Med J. 1988 Aug 20;74(4):184-6.

25. Slade AK, John RM, Swanton RH. Pseudoxanthoma elasticum presenting with myocardial infarction. Br Heart J. 1990 Jun;63(6):372-3.

26. Kundrotas L, Novak J, Kremzier J, Meenaghan M, Hassett J. Gastric bleeding in pseudoxanthoma elasticum. Am J Gastroenterol. 1988 Aug;83(8):868-72.

27. Belli A, Cawthorne S. Visceral angiographic findings in pseudoxanthoma elasticum. $\mathrm{Br} \mathrm{J}$ Radiol. 1988 May;61(725):368-71.

28. Drost $\mathrm{H}$, van Dam FE, Kluck HM. [Lifethreatening gastric bleeding in a patient with pseudoxanthoma elasticum]. Ned Tijdschr Geneeskd. 1982 Dec 11;126(50):2287-91.

29. Morgan AA. Recurrent gastrointestinal hemorrhage: an unusual cause. Am J Gastroenterol. 1982 Dec;77(12):925-8.

30. Keim HJ, Holtermüller KH, Walter U, Bork K, Rothmund M, Gabbert H. [Massive upper gastrointestinal bleeding as first clinical manifestation of pseudoxanthoma elasticum (author's transl)]. Z Gastroenterol. 1980 Jan;18(1):20-9.

31. Olbromska W. [Case of Grönblad-Strandberg syndrome associated with gastrointestinal bleeding]. Klin Oczna. 1973 Feb;43(2):189-91.

32. Van Waes L, Geerts ML, Beelaerts W, Demeulenaere L. [The Gronblad-StrandbergTouraine syndrome. Apropos of a case revealed by recurrent gastric hemorrhages (author's transl)]. Acta Gastroenterol Belg. 1973 Jun;36(6):302-9.

33. Gignoux R, Saint-Cyr M. [A case of total gastrectomy for gastric hemorrhage associated with Groenblad-Strandberg disease]. Lyon Chir. 1968 Oct;64(5):818-9. January 2022 Volume 6 Issue 1 
34. Dhers A, Badarou G, Saint-Cyr M. [Repeated digestive hemorrhages during Groenblad-

Strandberg-Touraine disease. Apropos of 3 cases]. Arch Fr Mal App Dig. 1966 Aug;55(7):665-74.

35. van den Berg JS, Hennekam RC, Cruysberg JR, Steijlen PM, Swart J, Tijmes N, et al. Prevalence of symptomatic intracranial aneurysm and ischaemic stroke in pseudoxanthoma elasticum. Cerebrovasc Dis. 2000 Aug;10(4):315-9.

36. Grant AK, Aldor TA. Haemorrhage into the upper part of the gastro-intestinal tract in three patients with heritable disorders of connective tissue. Australas Ann Med. 1967

Feb;16(1):75-9.

37. Bercovitch L, Leroux T, Terry S, Weinstock MA. Pregnancy and obstetrical outcomes in pseudoxanthoma elasticum. $\mathrm{Br} \mathrm{J}$ Dermatol. 2004 Nov;151(5):1011-8.

38. Neldner KH. Pseudoxanthoma elasticum Clin Dermatol Jan-Mar 1988;6:1-159. 